\title{
Heterogeneity of Plasma Insulin and Triglyceride Levels in Obesity Demonstrated by Family Study
}

\author{
Yoshisuke Maruhama, Ryuzo Abe, Fuminobu Okuguchi, \\ Akira Ohneda and Yoshio Goto \\ The Third Department of Internal Medicine, Tohoku University \\ School of Medicine, Sendai 980
}

\begin{abstract}
Maruhama, Y., Abe, R., Okuguchi, F., Ohneda, A. and Goto, Y. Heterogeneity of Plasma Insulin and Triglyceride Levels in Obesity Demonstrated by Family Study. Tohokn J. exp. Med., 1979, $128(1), 19-29$ _ Fifty relatives of 7 families with high prevalence of obesity were investigated and the possibility was shown that there were three forms of familial obesity - normoinsulinemic obesity, hyperinsulinemic obesity and diabetic obesity. In normoinsulinemic obesity, both glucose tolerance and plasma lipids were normal with a few exceptions whereas in hyperinsulinemic obesity, mild glucose intolerance and manifest hyperlipidemia, and in diabetic obesity, blunted insulinogenic index and more advanced glucose intolerance with slight hyperlipidemia existed. plasma insulin; plasma triglyceride; glucose tolerance; diabetes mellitus
\end{abstract}

Obesity, although usually defined as the excessive accumulation of body fat, does not seem to be uniform in its etiology and pathophysiology (Seltzer 1969). Generally, the elevated plasma insulin with or without glucose intolerance is recognized as the frequent abnormality in the obese (Karam et al. 1963; Perley and Kipnis 1966). However, it is noteworthy that neither hyperinsulinemia nor glucose intolerance was demonstrable in certain obese patients (Vague 1969; Björntorp and Sjöström 1971; Olefsky 1976), while in obese diabetics hyperglycemia rather than hyperinsulinemia is known to be the characteristic change (Soeldner 1971). It has also been shown that obese humans with manifest hyperinsulinemia are specifically complicated with the metabolic disorders such as hypertriglyceridemia and hepatic steatosis (Maruhama et al. 1975). It is not clear, however, whether the above suggested heterogeneity of obesity is attributed, for the most part, to the differences in the genetic backgrounds of the individual families or to those in the environmental factors. In a selected series of family study, we have shown that the combined disorders of hyperinsulinemia, hypertriglyceridemia and hepatic steatosis observed in the probands also existed in nearly half of the relatives including the juvenile ones (Maruhama et al. 1978). Thus, the hyperinsulinemic and hypertriglyceridemic obesity may possibly be the one specific form of genetic obesity. However, there have been few genetic analyses on other forms of obesity.

Received for publication, June 10, 1978.

Supported by research grants from the Ministry of Education, Science and Culture, Japan (Nos. 777117, 877132, 967048 \& 257170). 
In the present study the relatives of three series of obese probands, one with normal insulin and triglyceride levels, one with elevated insulin and triglyceride levels and the other with diabetes mellitus, were investigated for their insulin secretory function, glucose tolerance and plasma lipid levels. The purpose of this investigation is to clarify whether or not the abnormality in each proband would be the reflection of familial disorder and whether the heterogeneity of obesity could be demonstrated among the family groups.

\section{Subjects ANd Methods}

\section{Probands and relatives}

Seven obese subjects, 5 males and 2 females, who visited the Outpatient Department of the University Hospital because of obesity, hyperlipidemia or diabetes mellitus, and whose family history revealed frequent incidence of obesity were selected as probands for this family study. The diseases that are known to produce carbohydrate and lipid disorders secondarily were excluded from the probands. A total of 43 relatives (8-78 years old) of these 7 probands were investigated. These relatives included 23 obese subjects.

\section{Controls}

A total of $\mathbf{9 0}$ non-relative members including the spouses were examined in the previous series of family study and they were used as age- and sex-matched controls in this investigation. The data on these control subjects have been published (Maruhama et al. 1976, 1978).

\section{Examinations}

The probands and the relatives were instructed to remain on their regular diet that was usually high in earbohydrate $(2000-2500 \mathrm{kcal}$ diet containing $280-350 \mathrm{~g}$ of carbohydrate daily). Alcohol intake was prohibited during the 3 days prior to the examinations. The sampling of blood specimen for analyses of plasma lipids and lipoproteins and subsequent oral glucose tolerance test using $50 \mathrm{~g}$ of glucose $(1.75 \mathrm{~g} / \mathrm{kg}$ of glucose for children aged under 10 years old) were performed after 13-15 hr overnight fast, either in the Outpatient Department or in the participant's home. The examinations were performed in the same manner also in the controls (Maruhama et al. 1978). In the oral glucose tolerance test, samples of capillary (ear lobe) blood for glucose analysis as well as venous blood samples for plasma insulin estimation were obtained before, and 30,60,90 and 120 min after the glucose loading. Each capillary blood was immediately deproteinized. The venous blood samples obtained by the heparinized syringe and kept at $4^{\circ} \mathrm{C}$ were brought to the laboratory within $2 \mathrm{hr}$ after completion of the examinations. Plasma was separated by a refrigerated centrifuge.

\section{Analytical procedures}

All fasting plasma samples were inspected visually to evaluate the presence of chylomicron after $12 \mathrm{hr}$ at $4^{\circ} \mathrm{C}$ and then analysed for triglyceride (Fletcher 1968), total cholesterol (Zlatkis and Zak 1969) and patterns of lipoproteins using an agarose gel electrophoresis (Noble 1968). Blood glucose (Huggett and Nixon 1957) and plasma immunoreactive insulin (Morgan and Lazarow 1962) were measured for the samples during the oral glucose tolerance test.

Student's $t$-test was applied to examine statistical significance. 
Results

\section{Classification of families}

The abnormalities of glucose, insulin and lipids in the relatives, if present, were found to be almost similar to those in the probands. Furthermore, it was shown that the abnormal pattern was uniform within the family but was apparently different between families. Therefore, the families examined were classified into those of normoisulinemic obesity, hyperinsulinemic obesity and diabetic obesity in the data analysis.

Clinical and laboratory findings in the individual probands and relatives of each group of families thus classified were shown in Tables 1,2 and 3. In these tables, $\Sigma$ Glucose or $\Sigma$ Insulin, sum of 5 half-hourly blood glucose or plasma insulin values during the oral glucose tolerance test, was used as an index of glucose tolerance or glucose-stimulated insulin secretion. Insulinogenic index (30 $\mathrm{min})$, that is the increment of plasma insulin above fasting level in $\mu \mathrm{U} / \mathrm{ml}$ divided by the increment of blood glucose above fasting level in $\mathrm{mg} / 100 \mathrm{ml}$ at $30 \mathrm{~min}$ after the glucose loading, was used as an index of insulin secretory function at early phase of glucose tolerance test. The variables were judged as abnormally high when those exceeded the corresponding mean value +2 S.D. of the age- and sex-matched controls, and as abnormally low when those were below mean -1 s.D. of the matched controls. In the analysis of glucose intolerance, the relatives were regarded as diabetic when the peak blood glucose value during the oral glucose tolerance test exceeded $180 \mathrm{mg} / 100 \mathrm{ml}$ with the $2 \mathrm{hr}$ value more than $140 \mathrm{mg} / 100 \mathrm{ml}$ (Committee Report 1970). The subjects were regarded as having obesity when their relative body weight (see footnotes for Table 1) exceeded 120\%. The abnormalities found in the relatives and probands of each group of families were depicted in the pedigree charts of Fig. 1. The subjects' pedigree positions listed in Tables 1, 2 and 3 were shown in the corresponding pedigree chart of Fig. 1. As shown in these tables and Fig. 1, the abnormalities in glucose tolerance, insulin secretory function and plasma lipids in the obese relatives including the probands were apparently different between the family groups in spite of the similarity in the incidences and the degrees of obesity. In the hyperlipidemic subjects, lipoprotein electrophoresis revealed the increase in prebeta lipoprotein with or without the increase in beta lipoprotein showing mostly type IV and partly type IIb patterns. None of the subjects showed type III hyperlipoproteinemia. It is noteworthy that in all family groups obesity and other abnormal variables tended to follow vertical transmission.

\section{Comparison of the abnormalities in family groups}

The insulinogenic index $(30 \mathrm{~min})$, the responsiveness of pancreatic beta cells to the glucose stimulation, was normal in the normoinsulinemic families, significantly increased in the hyperinsulinemic families and blunted in the diabetic families with a few exceptions. Plasma insulin levels during the glucose tolerance test $(\Sigma$ 
TABLE 1. Clinical and laboratory findings

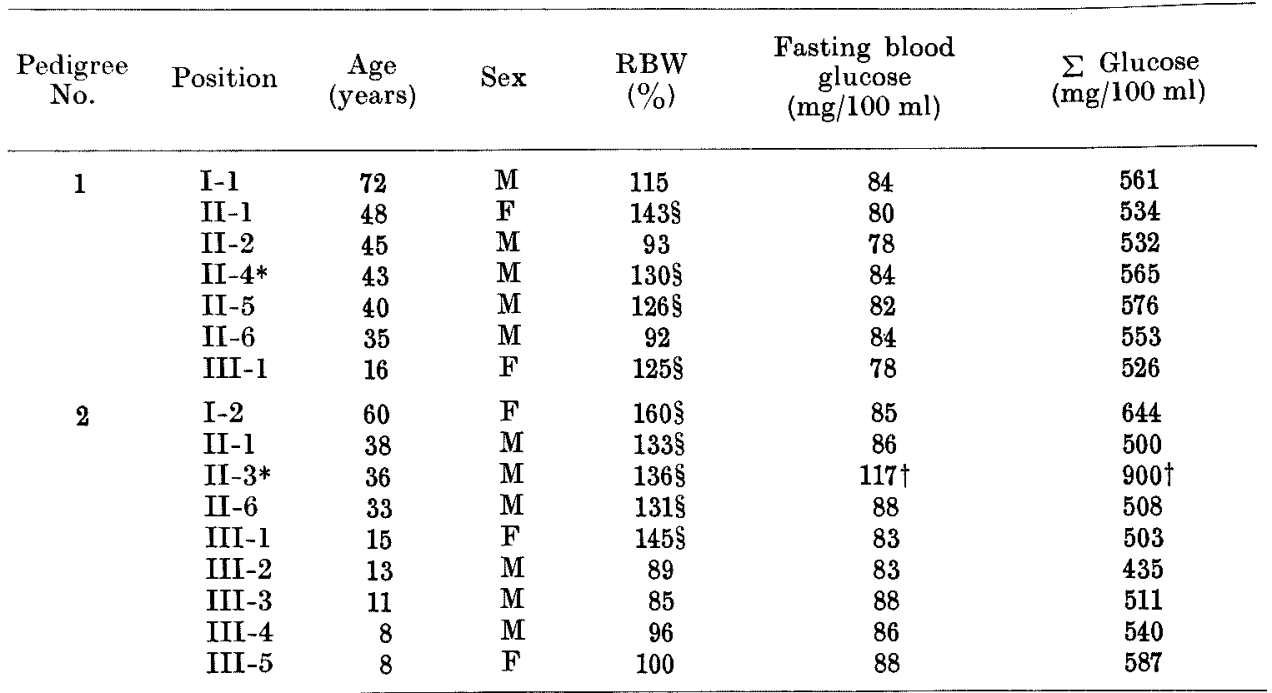

Position in pedigree is shown in each pedigree chart in Fig. 1. RBW : relative body (height in $\mathrm{cm}-100) \times 0.9 \mathrm{~kg}$. $\sum$ Glucose or $\sum$ Insulin: sum of 5 half-hourly blood glucose or increment of plasma insulin above fasting level of $\mu \mathrm{U} / \mathrm{ml}$ divided by increment of blood triglyceride. TC: total cholesterol.

+ Significantly higher than mean +2 s.D. of age- and sex-matched controls.

RBW was judged as abnormal (\$) when exceeded $120 \%$.

TABLE 2. Clinical and laboratory findings

\begin{tabular}{ccccccc}
\hline $\begin{array}{c}\text { Pedigree } \\
\text { No. }\end{array}$ & Position & $\begin{array}{c}\text { Age } \\
\text { (years) }\end{array}$ & Sex & $\begin{array}{c}\text { RBW } \\
(\%)\end{array}$ & $\begin{array}{c}\text { Fasting blood } \\
\text { glucose } \\
\text { (mg/100 ml }\end{array}$ & $\begin{array}{c}\sum \text { Glucose } \\
\text { (mg/100 ml) }\end{array}$ \\
\hline \multirow{2}{*}{1} & I-2 & 78 & F & $148 \S$ & 80 & 626 \\
& II-3 & 54 & M & 117 & 89 & 526 \\
& II-5* & 51 & M & $122 \S$ & $115 \dagger$ & $1003 \dagger$ \\
& II-7 & 47 & M & 93 & 82 & 530 \\
& II-8 & 45 & F & $120 \S$ & 76 & 560 \\
& III-1 & 25 & M & 86 & 85 & 533 \\
& III-2 & 21 & M & 96 & 79 & 740 \\
& III-3 & 20 & F & $129 \S$ & 84 & 554 \\
& III-4 & 19 & M & 100 & 91 & $811 \dagger$ \\
2 & I-1 & 64 & M & $138 \S$ & 88 & 579 \\
& I-2 & 38 & F & $133 \S$ & 80 & 591 \\
& I-3 & 60 & M & 98 & 80 & 658 \\
& II-1* & 15 & F & $158 \S$ & 74 & 637 \\
3 & I-1 & 42 & M & $138 \S$ & 89 & 521 \\
& I-2 & 37 & F & 115 & 82 & $838 \dagger$ \\
\hline
\end{tabular}

Footnotes are similar to those for Table 1. 
in families of normoinsulinemic obesity

\begin{tabular}{|c|c|c|c|c|}
\hline \multirow{2}{*}{$\begin{array}{l}\text { Fasting plasma } \\
\text { insulin } \\
(\mu \mathrm{U} / \mathrm{ml})\end{array}$} & \multirow{2}{*}{$\underset{(\mu \mathrm{U} / \mathrm{lm})}{\sum \text { Insulin }}$} & \multirow{2}{*}{$\begin{array}{c}\text { Insulinogenic } \\
\text { index } \\
(30 \mathrm{~min})\end{array}$} & \multicolumn{2}{|c|}{ Plasma } \\
\hline & & & $\begin{array}{c}\text { TG } \\
(\mathrm{mg} / 100 \mathrm{ml})\end{array}$ & $\begin{array}{c}\mathrm{TC} \\
(\mathrm{mg} / 100 \mathrm{ml})\end{array}$ \\
\hline 12 & 137 & 0.44 & 96 & 204 \\
\hline 10 & $85^{\ddagger}$ & 0.37 & 84 & 232 \\
\hline 12 & 133 & 0.49 & 102 & 220 \\
\hline 8 & 146 & 0.76 & 125 & 224 \\
\hline 6 & 193 & 1.17 & 80 & 232 \\
\hline 16 & 135 & 0.64 & 64 & 180 \\
\hline 15 & 139 & 0.54 & 92 & 201 \\
\hline 6 & 96 & 0.25 & 57 & 228 \\
\hline 13 & 83 & 1. 39 & 54 & 194 \\
\hline 12 & $63_{+}^{+}$ & $0.08_{\ddagger}^{+}$ & 109 & 221 \\
\hline 12 & 99 & 0.77 & 126 & 182 \\
\hline 5 & 99 & 0.64 & 47 & 171 \\
\hline 13 & 85 & 1.60 & 51 & 175 \\
\hline 12 & 99 & 0.91 & 78 & 199 \\
\hline 12 & $71 \ddagger$ & 0.43 & 96 & 169 \\
\hline 5 & 177 & 0.92 & 55 & 170 \\
\hline
\end{tabular}

weight $=($ actual body weight/standard body weight $) \times 100$. Standard body weight: plasma insulin values during oral glucose tolerance test. Insulinogenic index (30 min): glucose above fasting level in $\mathrm{mg} / 100 \mathrm{ml}$ at $30 \mathrm{~min}$ after oral glucose loading. TG: * Proband.

† Significantly lower than mean - 1 S.D. of age- and sex-matched controls.

in families of hyperinsulinemic obesity

\begin{tabular}{|c|c|c|c|c|}
\hline \multirow{2}{*}{$\begin{array}{c}\text { Fasting plasma } \\
\text { insulin } \\
(\mu \mathrm{U} / \mathrm{ml})\end{array}$} & \multirow[b]{2}{*}{$\underset{(\mu \mathrm{U} / \mathrm{ml})}{\sum \text { Insulin }}$} & \multirow{2}{*}{$\begin{array}{c}\text { Insulinogenic } \\
\text { index } \\
(30 \mathrm{~min})\end{array}$} & \multicolumn{2}{|c|}{ Plasma } \\
\hline & & & $\begin{array}{c}\mathrm{TG} \\
(\mathrm{mg} / 100 \mathrm{ml})\end{array}$ & $\begin{array}{c}\mathrm{TC} \\
(\mathrm{mg} / \mathrm{l} 00 \mathrm{ml})\end{array}$ \\
\hline 20 & $328{ }^{\dagger}$ & 0.69 & $333 \dagger$ & 148 \\
\hline 9 & 186 & 1.43 & 118 & 180 \\
\hline $66 \dagger$ & $906 \dagger$ & 0.86 & $813 \dagger$ & $438 \dagger$ \\
\hline 4 & 142 & 0.69 & 106 & 180 \\
\hline 12 & 464 & $1.91 \uparrow$ & $327 \dagger$ & 210 \\
\hline 6 & 229 & $2.24 \dagger$ & $176 \dagger$ & 191 \\
\hline 6 & 132 & $1.96 \dagger$ & 78 & 148 \\
\hline 19 & $444 \dagger$ & 1.68 & $173 \dagger$ & 200 \\
\hline 12 & $549 \dagger$ & 4. $35 \dagger$ & 37 & 160 \\
\hline 10 & $559 \dagger$ & 1.58 & $263^{\dagger}$ & 240 \\
\hline 12 & 94 & $0.33_{+}^{+}$ & $136 \dagger$ & 210 \\
\hline 11 & 120 & 0.68 & 83 & 200 \\
\hline 29 & $647 \dagger$ & $2.83 \uparrow$ & $252 \dagger$ & 225 \\
\hline 32 & $395 \dagger$ & 1.20 & $351 \dagger$ & 248 \\
\hline 12 & 206 & $0.35 \ddagger$ & 51 & 199 \\
\hline 14 & $376 \dagger$ & $2.87 \dagger$ & 116 & $224 \dagger$ \\
\hline $54 \dagger$ & $1537 \dagger$ & $1.83 \dagger$ & $462 \dagger$ & $262 \dagger$ \\
\hline
\end{tabular}


Table 3. Clinical and laboratory findings

\begin{tabular}{|c|c|c|c|c|c|c|}
\hline $\begin{array}{c}\text { Pedigree } \\
\text { No. }\end{array}$ & Position & $\begin{array}{c}\text { Age } \\
\text { (years) }\end{array}$ & Sex & $\begin{array}{c}\text { RBW } \\
(\%)\end{array}$ & $\begin{array}{l}\text { Fasting blood } \\
\text { glucose } \\
(\mathrm{mg} / 100 \mathrm{ml})\end{array}$ & $\underset{(\mathrm{mg} / 100 \mathrm{ml})}{\sum \text { Glucose }}$ \\
\hline 1 & $\begin{array}{l}\text { I-1 } \\
\text { I-2 } \\
\text { II-1* } \\
\text { II-2 } \\
\text { II-3 } \\
\text { II-4 }\end{array}$ & $\begin{array}{l}69 \\
64 \\
39 \\
37 \\
34 \\
31\end{array}$ & $\begin{array}{l}M \\
\text { F } \\
M \\
M \\
M \\
M\end{array}$ & $\begin{array}{c}145 \S \\
145 \S \\
141 \S \\
96 \\
141 \S \\
89\end{array}$ & $\begin{array}{c}135 \dagger \\
85 \\
109 \dagger \\
90 \\
141 \dagger \\
84\end{array}$ & $\begin{array}{c}\mathbf{9 4 0} \dagger^{\dagger} \\
\mathbf{5 5 0} \\
\mathbf{9 4 8} \dagger \\
\mathbf{5 6 6} \\
1184 \dagger \\
\mathbf{5 5 4}\end{array}$ \\
\hline 2 & $\begin{array}{l}\text { I-2 } \\
\text { II-1 } \\
\text { II-3 } \\
\text { II-5 } \\
\text { II-6* } \\
\text { II-7 } \\
\text { II-8 } \\
\text { II-9 } \\
\text { III-2 } \\
\text { III-3 } \\
\text { III-4 }\end{array}$ & $\begin{array}{l}73 \\
53 \\
51 \\
47 \\
45 \\
46 \\
40 \\
37 \\
24 \\
18 \\
16\end{array}$ & $\begin{array}{l}\mathrm{F} \\
\mathrm{F} \\
\mathrm{F} \\
\mathrm{M} \\
\mathrm{F} \\
\mathrm{M} \\
\mathbf{F} \\
\mathbf{F} \\
\mathrm{M} \\
\mathbf{F} \\
\mathrm{M}\end{array}$ & $\begin{array}{c}135 \S \\
151 \S \\
128 \S \\
121 \S \\
120 \S \\
86 \\
137 \S \\
130 \S \\
128 \S \\
106 \\
84\end{array}$ & $\begin{array}{c}115 \dagger \\
89 \\
111 \dagger \\
202 \dagger \\
194 \dagger \\
89 \\
94 \\
77 \\
85 \\
79 \\
83\end{array}$ & $\begin{array}{c}1120 \dagger \\
520 \\
825 \dagger \\
1575 \dagger \\
1351 \dagger \\
510 \\
749 \dagger \\
609 \\
498 \\
511 \\
532\end{array}$ \\
\hline
\end{tabular}

Footnotes are similar to those for Table $\mathbf{l}$.

Insulin) was normal in the relatives of the normoinsulinemic families except for 3 cases, definitely increased in those of the hyperinsulinemic families and normal or decreased in those of the diabetic families. Blood glucose during the glucose tolerance test ( $\Sigma$ Glucose) revealed normal value except in one case in the relatives of the normoinsulinemic families and it showed the borderline or diabetic values in each 2 cases of the hyperinsulinemic families. Glucose intolerance, if present, was mostly the diabetic one associated with the decreased insulinogenic index $(30 \mathrm{~min})$ in the relatives of diabetic obesity. Hyperlipidemia was not found in the normoinsulinemic families. Hypertriglyceridemia with or without hypercholesterolemia was noted frequently in the relatives of the hyperinsulinemic families as well as in those of the diabetic families. Therefore, the characteristic feature in the normoinsulinemic families is obesity without other abnormalities, that in the hyperinsulinemic families is the combination of the increased insulin secretion and hypertriglyceridemia, and that in the diabetic families is the combination of defective early insulin response, diabetic glucose tolerance curve and hypertriglyceridemia. These findings in the relatives including the probands were summarized in Table 4 according to the family groups.

In order to compare insulinogenic index $(30 \mathrm{~min}), \Sigma$ Insulin, $\Sigma$ Glucose and plasma lipids among the obese relatives (relative body weight $>120 \%$ ), including the probands, of these 3 groups of families, the variables adjusted for age and sex and pooled were averaged in each family group. Since the mean value and standard deviation of each variable were almost the same between both sexes in the controls of age range of 41-60 years (Maruhama et al. 1976), the individual values of the obese relatives were adjusted according to the following formula: 
in families of diabetic obesity

\begin{tabular}{|c|c|c|c|c|}
\hline \multirow{2}{*}{$\begin{array}{c}\text { Fasting plasma } \\
\text { insulin } \\
(\mu \mathrm{U} / \mathrm{ml})\end{array}$} & \multirow{2}{*}{$\underset{(\mu \mathrm{U} / \mathrm{ml})}{\sum \text { Insulin }}$} & \multirow{2}{*}{$\begin{array}{c}\text { Insulinogenic } \\
\text { index } \\
(30 \mathrm{~min})\end{array}$} & \multicolumn{2}{|c|}{ Plasma } \\
\hline & & & $\begin{array}{c}\mathrm{TG} \\
(\mathrm{mg} / 100 \mathrm{ml})\end{array}$ & $\begin{array}{c}\mathrm{TC} \\
(\mathrm{mg} / 100 \mathrm{ml})\end{array}$ \\
\hline 18 & 246 & 0.88 & 143 & 195 \\
\hline 12 & 164 & $\begin{array}{l}0.62 \\
0.62\end{array}$ & $\begin{array}{r}170 \\
53\end{array}$ & 224 \\
\hline 16 & 212 & $0.29^{\ddagger}$ & $170 \dagger$ & $\begin{array}{l}234 \\
230\end{array}$ \\
\hline 10 & 128 & 1.00 & 78 & 205 \\
\hline 15 & 158 & $0.04^{+}$ & $195 \dagger$ & 241 \\
\hline 14 & 144 & 0.43 & 102 & 214 \\
\hline 8 & 103 & $0.08_{\ddagger}^{+}$ & 120 & 240 \\
\hline 11 & 266 & 1.25 & $136 \dagger$ & 211 \\
\hline 11 & 117 & $0.24_{t}^{+}$ & $131 \dagger$ & $290 \dagger$ \\
\hline 14 & $83_{+}^{+}$ & $0.04_{+}^{+}$ & $325 \dagger$ & $272 \dagger$ \\
\hline 11 & $21_{+}^{+}$ & $0.08_{t}^{+}$ & $410 \dagger$ & $265 \dagger$ \\
\hline 15 & $72_{+}^{+}$ & 1. 02 & 137 & 196 \\
\hline 20 & 156 & $0.04 t$ & 98 & 207 \\
\hline 10 & 282 & 0.58 & $136 \dagger$ & $267 \dagger$ \\
\hline 4 & 123 & 1.29 & 95 & 236 \\
\hline 9 & 241 & 1.60 & 127 & 157 \\
\hline 13 & 226 & 1.19 & 88 & 166 \\
\hline
\end{tabular}

Adjusted value $=$ (observed value - control mean value of appropriate age and sex $)+$ mean value of the controls of age range of 41-60 years of appropriate sex.

As shown in Table 5, no difference was found in the degree of obesity between the obese relatives of the 3 family groups. Insulinogenic index ( $30 \mathrm{~min}$ ) was markedly high in the obese relatives of the hyperinsulinemic families as compared to that in other family groups. As mentioned above, insulinogenic index (30 min) was frequently blunted in the whole relatives of the diabetic families (Table 4). However, in the obese relatives of the diabetic families, insulinogenic index was decreased slightly but not significantly, as compared to that in the controls or in the obese relatives of the normoinsulinemic families. $\Sigma$ Insulin was most increased in the obese relatives of the hyperinsulinemic families. Unexpected is that $\Sigma$ Insulin was rather low, on an average, in the obese relatives of the normoninsulinemic families. $\Sigma$ Glucose was most increased in the obese relatives of the diabetic families. $\Sigma$ Glucose was also greater in the obese relatives of the hyperinsulinemic family group than in the obese relatives of the normoinsulinemic family group. No significant difference was noted in $\Sigma$ Glucose between the obese relatives of the hyperinsulinemic and diabetic family groups. The average plasma triglyceride value was normal in the obese relatives of the normoinsulinemic families. The increase in plasma triglyceride was most prominent in the obese relatives of the hyperinsulinemic families as shown in Table 5. The plasma triglyceride level was also elevated significantly in the obese relatives of the diabetic family group as compared to that in the controls or in the normoinsulinemic family group. However, the magnitude of hypertriglyceridemia in the hyperinsulinemic families was far greater than that in the diabetic families. Plasma 
Normoinsulinemic obesity

Pedigree 1

Pedigree 2

II
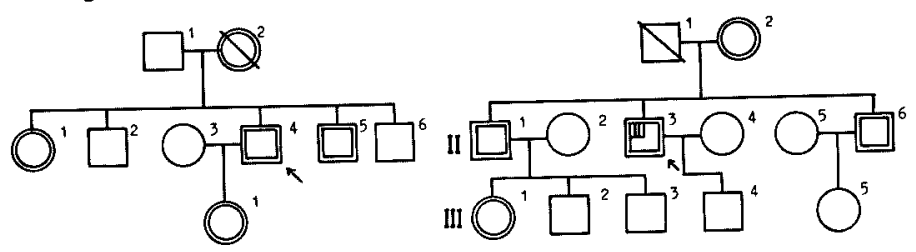

Hyperinsulinemic obesity

Pedigree 1

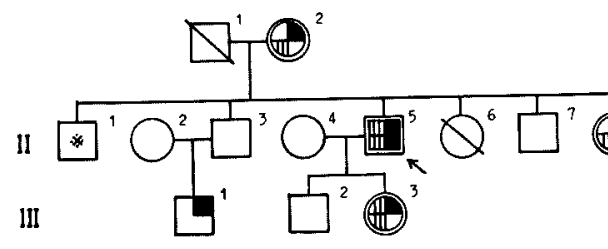

Diabetic obesity

Pedigree 1

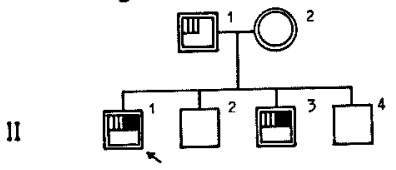

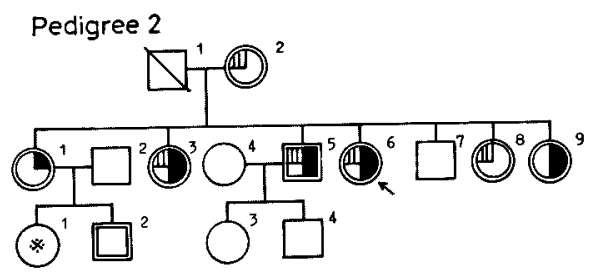
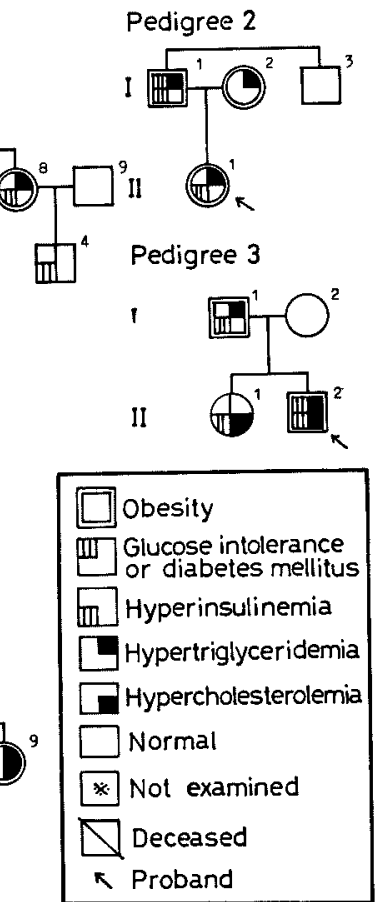

Fig. 1. Abnormal findings in glucose tolerance and plasma insulin and lipid levels in pedigrees of normoinsulinemic obesity, hyperinsulinemic obesity and diabetic obesity.

total cholesterol was elevated slightly but significantly in the obese relatives of either hyperinsulinemic family group or diabetic family group.

\section{Discussion}

The heterogeneity in the pathophysiology of obesity has been well-recognized (Seltzer 1969), and the present study suggests that this heterogeneity originates from the familial basis. In general population, simple obesity without glucose intolerance, hyperinsulinemia and hyperlipidemia is not uncommon; Björntorp and Sjöström (1971) reported that this form of obesity revealed a characteristic 
TABLE 4. Incidence of abnormal findings in families of normoinsulinemic obesity, hyperinsulinemic obesity and diabetic obesity

\begin{tabular}{|c|c|c|c|c|c|c|c|c|c|c|}
\hline \multirow{2}{*}{ Family } & \multirow{2}{*}{$\begin{array}{l}\text { Number } \\
\text { of } \\
\text { relatives } \\
\text { examined }\end{array}$} & \multirow{2}{*}{ Obesity } & \multicolumn{2}{|c|}{$\begin{array}{l}\text { Insulinogenic } \\
\text { index }(30 \mathrm{~min})\end{array}$} & \multicolumn{2}{|c|}{$\Sigma$ Insulin } & \multicolumn{2}{|c|}{$\begin{array}{l}\text { Glucose } \\
\text { tolerance }\end{array}$} & \multirow{2}{*}{$\begin{array}{l}\text { Hyper- } \\
\text { trigly- } \\
\text { ceri- } \\
\text { demia }\end{array}$} & \multirow{2}{*}{$\begin{array}{l}\text { Hyper- } \\
\text { chole- } \\
\text { stero- } \\
\text { lemia }\end{array}$} \\
\hline & & & $\begin{array}{l}\text { Inc- } \\
\text { reased }\end{array}$ & Blunted & $\begin{array}{l}\text { Inc- } \\
\text { reased }\end{array}$ & $\begin{array}{l}\text { Dec- } \\
\text { reased }\end{array}$ & $\begin{array}{l}\text { Border- } \\
\text { line } \\
\text { abnormal }\end{array}$ & $\begin{array}{l}\text { Dia- } \\
\text { betic }\end{array}$ & & \\
\hline $\begin{array}{l}\text { Normo- } \\
\text { insuli- } \\
\text { nemic } \\
\text { obesity }\end{array}$ & 16 & 9 & 0 & 1 & 0 & 3 & 0 & 1 & 0 & 0 \\
\hline $\begin{array}{l}\text { Hyper- } \\
\text { insuli- } \\
\text { nemic } \\
\text { obesity }\end{array}$ & 17 & & & 2 & 10 & 1 & 2 & 2 & 10 & 3 \\
\hline $\begin{array}{c}\text { Diabetic } \\
\text { obesity }\end{array}$ & 17 & 12 & $u$ & & 0 & 3 & & & & 4 \\
\hline
\end{tabular}

The relatives were judged to have obesity when their relative body weight exceeded $120 \%$. Insulinogenic index and $\Sigma$ Insulin were regarded as increased when those exceeded mean +2 s.D. of age- and sex-matched controls, and as blunted or decreased when those were below mean -1 s.D. of the matched controls. Glucose tolerance was judged as borderline abnormal when $\Sigma$ Glucose during oral glucose tolerance test exceeded mean +2 s.D. of the matched controls, and as diabetic according to the criteria of the Japan Diabetic Society (see text). The relatives were regarded to have hypertriglyceridemia or hypercholesterolemia when their plasma triglyceride or total cholesterol levels exceeded mean +2 s.D. of the matched controls.

TABLE 5. Age-and sex-adjusted variables in controls and in obese relatives of families with normoinsulinemic obesity, hyperinsulinemic obesity and diabetic obesity

\begin{tabular}{|c|c|c|c|c|c|c|}
\hline & \multirow{2}{*}{$\begin{array}{c}\text { Relative } \\
\text { body } \\
\text { weight } \\
(\%)\end{array}$} & \multirow{2}{*}{$\begin{array}{c}\text { Insulinogenic } \\
\text { index } \\
(30 \mathrm{~min})\end{array}$} & \multirow[b]{2}{*}{$\underset{(\mu \mathrm{U} / \mathrm{ml})}{\sum \text { Insulin }}$} & \multirow[b]{2}{*}{$\underset{(\mathrm{mg} / 100 \mathrm{ml})}{\sum \text { Glucose }}$} & \multicolumn{2}{|c|}{ Plasma } \\
\hline & & & & & $\begin{array}{c}\text { TG } \\
(\mathrm{mg} / 100 \mathrm{ml})\end{array}$ & $\begin{array}{c}\mathrm{TC} \\
(\mathrm{mg} / 100 \mathrm{ml})\end{array}$ \\
\hline Controls $(n=90)$ & $115 \pm 2$ & $0.74 \pm 0.06$ & $173 \pm 8$ & $558 \pm 7$ & $93 \pm 4$ & $197 \pm 3$ \\
\hline $\begin{array}{l}\text { Normoinsulinemic } \\
\text { obesity }(n=9)\end{array}$ & $137 \pm 3^{a}$ & $0.66 \pm 0.14$ & $111 \pm 13^{\mathrm{a}}$ & $58 \pm \pm 42$ & $86 \pm 10$ & $209 \pm 8$ \\
\hline $\begin{array}{l}\text { Hyperinsulinemic } \\
\text { obesity }(n=9)\end{array}$ & $136 \pm 4^{2}$ & $1.43 \pm 0.25^{\mathrm{ab}}$ & $507 \pm 143^{a b}$ & $708 \pm 49^{\mathrm{ab}}$ & $346 \pm 67^{\mathrm{ab}}$ & $242 \pm 27^{\mathrm{a}}$ \\
\hline $\begin{array}{l}\text { Diabetic obesity } \\
(n=12)\end{array}$ & $135 \pm 3^{\mathrm{a}}$ & $0.45 \pm 0.14^{c}$ & $161 \pm 23^{c}$ & $906 \pm 101^{a b}$ & $168 \pm 29^{\mathrm{abc}}$ & $240 \pm 8^{a b}$ \\
\hline
\end{tabular}

Mean values \pm S.E. in controls and in obese relatives (relative body weight $>120 \%$ ) of each family group were shown. See text for age- and sex-adjustment of variables. a: Significantly $(p<0.05)$ different from the values of controls.

b: Significantly $(p<0.05)$ different from the values of normoinsulinemic obesity. c: Significantly $(p<0.05)$ different from the values of hyperinsulinemic obesity. Annotations for the variables are similar to those in footnotes for Table 1.

increase in the number of the adipocytes with normal cell size while Olefsky (1976) demonstrated that the number of insulin receptors in adipocytes in obese humans without hyperinsulinemia, in contrast to that in those with hyperinsulinemia, was 
not decreased. Although neither the adipocyte cellularity nor the insulin receptor was examined in this investigation, the characteristics found by the above authors might exist in this familial obesity. Overall, the increased adipose tissue mass is the only abnormality and the metabolism in carbohydrate and lipids seems to be normally maintained in this disorder. On the other hand, hyperinsulinemic obesity is often accompanied by hyperlipidemia as well as hepatic steatosis (Maruhama et al. 1975; Kral et al. 1977), and this has also been shown to be one specific form of familial obesity (Maruhama et al. 1978). In this disorder the insulin hypersecretion might be the basic trait as suggested in the exaggerated insulinogenic index in this group of families. Thus, the sustained hyperinsulinemia could accelerate hepatic lipid synthesis leading to the increased scretion of triglyceride-rich very low density lipoprotein as well as to hepatic steatosis in the extreme cases, as suggested in genetic hyperinsulinemic animals (Iwatsuka et al. 1970; Assimacopoulos-Jeannet et al. 1974) and in humans (Kral et al. 1977).

In the families of diabetic obesity, the insulin hypersecretion is not noted and the early insulin secretory response after glucose stimulation is rather blunted. Glucose tolerance is most impaired in the families of diabetic obesity with a slight elevation of plasma lipids.

It has been considered that diabetes mellitus may develop in obese hyperinsulinemic subjects with a long duration since pancreatic beta cells may become less active with aging and other factors. In fact, it has been shown that mild, but not overt, diabetes mellitus was frequent $(11 \%)$ in 81 relatives of familial hyperinsulinemia and that there might be some linkage and no clear-cut separation between familial hyperinsulinemia and diabetes mellitus (Maruhama et al. 1978). However, the analysis of the present data on the families of the diabetic probands revealed that none of the obese relatives was hyperinsulinemic. Thus, we rather take a step forward to the suggestion that "diabetes mellitus" in the hyperinsulinemic obesity and diabetes mellitus characterized by the defective early insulin response to glucose might be the different familial disorders, although a longitudinal study is needed to establish this segregation.

In the present study, the abnormalities tended to show vertical transmission in most pedigrees suggesting autosomal dominant transmission of each form of obesity. However, in view of the limited sample size and parameters examined, no conclusion could be drawn on the mode of inheritance.

\section{References}

1) Assimacopoulos-Jeannet, F., Singh, A., Marchand, Y. Le., Loten, E.G. \& Jeanrenaud, B. (1974) Abnormalities in lipogenesis and triglyceride secretion by perfused livers of obese-hyperglycemic (ob/ob) mice. Relationship with hyperinsulinemia. Diabetologia, $10,155-162$.

2) Björntorp, P. \& Sjöström, L. (1971) Number and size of adipose tissue fat cells in relation to metabolism in human obesity. Metabolism, 20, 703-713.

3) Committee Report (1970) Diagnostic criteria of diabetes mellitus by oral glucose tolerance test. J. Jap. Diab. Soc., 13, 7. 
4) Fletcher, M.J. (1968) A colorim tric method for estimating serum triglycerides. Clin. chim. Acta, 22, 393-397.

5) Huggett, A. St. G. \& Nixon, D.A. (1957) Use of glucose oxidase, peroxidase and o-dianisidine in determination of blood and urinary glucose. Lancet, 2, 368-370.

6) Iwatsuka, H., Shino, A. \& Suzuoki, Z. (1970) General survey of diabetic features of yellow KK mice. Endocr. Japon., 17, 23-35.

7) Karam, J.H., Grodsky, G.M. \& Forsham, P.H. (1963) Excessive insulin response to glucose in obese subjects as measured by immunochemical assay. Diabetes, 12, 197-204.

8) Kral, J.G., Lundholm, K., Björntorp, P., Sjöström, L. \& Schersten, T. (1977) Hepatic lipid metabolism in severe human obesity. Metabolism, 26, 1025-1031.

9) Maruhama, Y., Ohneda, A., Tadaki, H., Ohtsuki, M., Yanbe, A., Abe, R. \& Yamagata, S. (1975) Hepatic steatosis and the elevated plasma insulin level in patients with endogenous hypertriglyceridemia. Metabolism, 24, 653-664.

10) Maruhama, Y., Abe, R., Okuguchi, F. \& Ohneda, A. (1976) Evidence for a familial form of hypэrtriglyceridemia as disorders coupled with insulin resistance. Tohoku $J$. exp. Med., 120, 83-89.

11) Maruhama, Y., Abe, R., Okuguchi, F., Oikawa, S., Ohneda, A. \& Goto, Y. (1978) Interactions of obesity and glucose-stimulated insulin secretion in familial hypertriglyceridemia. Diabetes, 27, 682-693.

12) Morgan, C.R. \& Lazarow, A. (1962) Immunoassay of insulin using a two-antibody system. Proc. Soc. exp. Biol. Med., 110, 29-32.

13) Noble, R.P. (1968) Electrophoretic separation of plasma lipoproteins in agarose gel. J. Lipid Res., 9, 693-700.

14) Olefsky, J.M. (1976) Decreased insulin binding to adipocytes and circulating monocytes from obese subjects. J. clin. Invest., 57, 1165-1172.

15) Perley, M. \& Kipnis, D.M. (1966) Plasma insulin responses to glucose and tolbutamide of normal weight and obese diabetic and nondiabetic subjects. Diabetes, 15, 867-874.

16) Seltzer, C.C. (1969) Genetics and obesity. In: Physiopathology of Adipose Tissue, edited by J. Vague \& R.M. Denton, Excerpta Medica, Amsterdam, pp. 325-334.

17) Soeldner, J.S. (1971) Insulin in diabetes-Applied physiology. In: Joslin's Diabetes Mellitus, edited by A. Marble, P. White, R.F. Bradley \& L.P. Krall, Lea \& Febiger, Philadelphia, pp. 99-138.

18) Vague, Ph., Boeuf, G., Depieds, R. \& Vague, J. (1969) Plasma insulin levels in human obesity. In: Physiopathology of Adipose Tissue, edited by J. Vague \& R.M. Denton, Excerpta Medica, Amsterdam, pp. 203-225.

19) Zlatkis, A. \& Zak, B. (1969) Study of a new cholesterol reagent. Analyt. Biochem., $29,143-148$. 